\title{
Pengaruh Struktur Modal, Struktur Aset, Laba Bersih, Piutang Usaha, Likuiditas, Profitabilitas terhadap Arus Kas
}

\author{
Tatema Hondro $^{1 *}$, Masriani Laia ${ }^{2}$, Mataniria Nduru ${ }^{3}$, Bayu Wulandari ${ }^{4}$ \\ Universitas Prima Indonesia \\ tatemahondro3443@gmail.com, laiamasriani@gmail.com, mastanirianduru@gmail.com \\ bayuwulandari@unprimdn.ac.id
}

* Penulis Korespondensi

Dikirim : : 14 Juni 2021

Diterima : 11 Juli 2021

Dipublikasi : 1 Agustus 2021

\begin{abstract}
The purpose of this study was to see and test whether the effect of capital structure, asset structure, net income, accounts receivable, liquidity, profitability variable to cash flows variable on the value of service companies listed on the IDX (Indonesia Stock Exchange) from 2017-2019. This research uses a method with a quantitative descriptive approach. The population obtained was 78 companies listed on the Indonesia Stock Exchange from 2017-2019. The sample used in this study was purposive sampling technique. The sample obtained was 12 companies. The data analysis used several analyzes, namely multiple linear analysis, the coefficient of determination test, the classical assumption test, the F test, and the test. This study shows that partially the variables of capital structure, asset structure, accounts receivable, liquidity, ROE have no effect on cash flow variables at service companies that listed on the Indonesia Stock Exchange, while the net income variable has an influence on cash flow variables at service companies listed in Indonesia Stock Exchange, and simultaneously the variables of capital structure, asset structure, net income, accounts receivable, liquidity, Return On Equity do not have an influence on cash flow variables in service companies that listed on the Indonesia Stock Exchange.
\end{abstract}

Keywords: Account Receivable; Asset Structure; Capital Structure; Liquidity and Net Income

\section{PENDAHULUAN}

Pada dasarnya arus kas adalah proses perincian pemasukan dan pengeluaran perusahaan pada periode tertentu. Di dalam keuangan perusahaan bisnis yang terdapat di cash basis dan accrual basis. Di dalam laporan arus kas biasanya meliputi jumlah kas yang diterima. Menurut PSAK (IAI 2009: 1) laporan keuangan adalah suatu penyajian terstruktur dari posisi keuangan dan kinerja keuangan suatu entitas. Tujuan laporan keuangan adalah memberikan informasi mengenai posisi keuangan, kinerja keuangan, dan arus kas entitas yang bermanfaat bagi sebagian besar kalangan pengguna laporan dalam pembuatan keputusan ekonomi. Laporan keuangan juga menentukan hasil pertanggungjawaban manajemen atas penggunaan sumberdaya yang dipercayakan kepada mereka.

Arus kas dari aktivitas operasi merupakan indikator yang menentukan apakah arus kas operasi perusahaan dapat menghasilkan arus kas cukup untuk melunasi pinjaman, membayar deviden dan melakukan investasi baru tanpa mengandalkan sumber pendanaan dari luar. Beberapa penelitian terdahulu tentang pengaruh kemampuan arus kas dan laba terhadap arus kas masa depan menunjukkan adanya perbedaan hasil yang diperoleh. Ditemukan penelitian yang dilakukan Titin (Rinanda et al., 2018), pengaruh kemampuan prediktif laba dan arus kas operasi dalam memprediksi arus kas operasi masa depan, menyatakan bahwa laba dan arus kas operasi berpengaruh secara signifikan terhadap arus kas operasi dimasa depan. Struktur modal adalah bagian terpenting didalam perusahaan. Jika suatu perusahaan memiliki masalah maka akan memiliki pengaruh langsung terhadap posisi keuangan perusahaan. Masing-masing dapat 
mempengaruhi kondisi keuangan dalam perusahaan, dapat mempengaruhi harga saham dalam perusahaan.

Aset salah satu hal penting dalam terpenuhinya kebutuhan dalam perusahaan. Struktur aset dapat menggambarkan keseimbangan antara total aset dengan aset tetap dalam suatu perusahaan. Menurut Bambang Riyanto (Nursyam et al., 2020), "Struktur kekayaan ialah perimbangan baik dalam artian absolute maupun dalam artian relative antara aktiva lancar dan aktiva tetap. Laba bersih total pendapatan yang melebihi jumlah modal yang telah dikeluarkan untuk sebuah proses produksi. Laba bersih juga merupakan perolehan dalam tahun buku berjalan setelah dikurangi beban pajak penghasilan. Menurut Hansen dan Mowen (Nur Islamiyah, Rita Andini,2018), "Laba adalah pendapatan operasional dikurangi pajak, biaya bunga, biaya penelitian dan pengembangan. Laba bersih disajikan dalam laporan laba rugi dengan membandingkan pendapatan dan biaya. Piutang usaha adalah pembelian jasa atau barang yang dilakukan secara kredit oleh pelanggan secara terutang. Biasanya pada laporan keuangan piutang usaha terdapat pada bagian aktiva lancar. Likuiditas adalah kemampuan seseorang atau perusahaan dalam membayar hutang jangka pendek. Karena sebuah perusahaan dapat nilai menggunakan likuiditas, semakin besar nilai likuiditasnya maka dapat menunjukkan kinerja yang baik pada suatu perusahaan. Profitabilitas merupakan adanya kemampuan pada perusahaan untuk mendapatkan laba dalam waktu tertentu pada penjualan asset dan modal saham. Dalam mengukur efesiensi penggunaan modal pada perusahaan dapat menggunakan profitabilitas yaitu dengan membandingkan keuntungan dengan modal yang akan digunakan.

Tabel 1. Tabel Fenomena

\begin{tabular}{|c|l|l|l|l|l|l|l|l|}
\hline $\begin{array}{c}\text { Kode } \\
\text { Emiten }\end{array}$ & Tahun & \multicolumn{1}{|c|}{$\begin{array}{c}\text { Struktur } \\
\text { Modal }\end{array}$} & \multicolumn{1}{|c|}{ Struktur Aset } & Laba Bersih & $\begin{array}{c}\text { Piutang } \\
\text { Usaha }\end{array}$ & Likuiditas & Profitabilitas & Arus Kas \\
\hline \multirow{3}{*}{ RANC } & 2017 & 41.203 .822 & 804.020 .324 & 37.685 .584 & 77.927 .974 & 343.417 .617 & 460.602 .707 & 166.739 .021 \\
\cline { 2 - 8 } & 2018 & 51.292 .877 & 904.003 .739 & 49.966 .984 & 60.756 .618 & 399.959 .714 & 504.044 .024 & 246.393 .790 \\
\cline { 2 - 8 } & 2019 & 56.067 .821 & 952.496 .300 & 55.464 .434 .251 & 45.433 .342 & 404.693 .066 & 547.803 .234 & 259.300 .425 \\
\hline \multirow{3}{*}{ MIDI } & 2017 & 1.223 .030 & 4.878 .115 & 102.812 & 250.673 & 3.955 .245 & 922.870 & 229.109 \\
\cline { 2 - 9 } & 2018 & 919.451 & 4.960 .145 & 159.154 & 1.203 .686 & 3.879 .324 & 1.080 .821 & 196.898 \\
\cline { 2 - 8 } & 2019 & 870.846 & 4.990 .309 & 203.070 & 80.856 & 3.769 .310 & 1.220 .999 & 241.125 \\
\hline \multirow{3}{*}{ DAYA } & 2017 & 33.767 .641 & 275.798 .556 & 3.981 .186 & 51.728 .227 & 154.880 .476 & 120.828 .080 & 70.639 .350 \\
\cline { 2 - 8 } & 2018 & 10.290 .151 & 411.861 .480 & 5.199 .245 & 97.492 .613 & 248.458 .704 & 163.402 .776 & 73.923 .173 \\
\cline { 2 - 8 } & 2019 & 149.071 .567 & 730.497 .952 & 18.539 .711 & 34.270 .233 & 560.812 .496 & 169.685 .456 & 68.773 .985 \\
\hline \multirow{3}{*}{ ACES } & 2017 & 440.210 .145 & 4.428 .840 .550 & 780.686 .814 & 536.202 .557 & 918.418 .702 & 3.510 .421 .847 & 902.227 .973 \\
\cline { 2 - 8 } & 2018 & 454.654 .350 & 5.321 .180 .855 & 976.273 .356 & 738.008 .173 & 1.085 .709 .809 & 4.235 .471 .045 & 798.522 .144 \\
\cline { 2 - 8 } & 2019 & 610.057 .043 .432 & 5.920 .169 .803 .449 & 1.036 .610 .556 & 488.048 .340 & 1.177 .675 .527 & 4.742 .494 .275 & 1.255 .018 .477 \\
\hline
\end{tabular}

Sumber: www.idx.co.id

Pada tabel 1, terlihat data fluktuasi pada PT. Supra Boga Lestari Tbk persentase SM tahun 2017\&2018 mengalami kenaikan Rp.10.089.055.312 persentasi SA tahun 2017\&2018 mengalami kenaikan Rp.99.983.414.973 persentase LB tahun 2017\&2018 mengalami kenaikan Rp.12.281.399.746 persentase PU tahun $2017 \& 2018$ mengalami penurunan Rp.17.171.356.589 persentase LK tahun 2017\&2018 mengalami kenaikan Rp.56.542.097.521 persentasi PROF tahun 2017\&2018 mengalami kenaiakan Rp.43.441.317.056 persentase AR tahun 2017\&2018 mengalami kenaikan Rp.79.654.769.059.

Pada PT. Midi Utama Indonesia Tbk persentase SM tahun $2018 \& 2019$ mengalami penurunan Rp.48.605 persentasi SA tahun 2018\&2019 mengalami kenaikan Rp.30.164 persentase LB tahun 2018\&2019 mengalami kenaikan Rp.43.916 persentase PU tahun 2018\&2019 mengalami penurunan RP.1.122.830 persentase LK tahun 2018\&2019 mengalami penurunan Rp.110.014 persentase PROF tahun 2018\&2019 mengalami kenaikan Rp.140.178 persentase AR tahun 2018\&2019 mengalami keniakan Rp.44.227.

Pada PT. Duta Intidaya Tbk persentase SM tahun 2018\&2019 mengalami kenaikan Rp.138.781.416 persentase SA tahun 2018\&2019 mengalami kenaikan Rp.318.636.472 persentase LB tahun 2018\&2019 mengalami kenaikan Rp.13.340.466 persentase PU tahun 2018\&2019 
mengalami penurunan Rp.63.222.380 persentase LK tahun 2018\&2019 mengalami kenaikan Rp.312.353.792 persentase PROF tahun 2018\&2019 mengalami kenaikan Rp.6.282.680 persentase AR tahun 2018\&2019 mengalami penurunan Rp.5.149.188.

Pada PT. Ace Hardware Indonesia Tbk persentase SM tahun 2017\&2018 mengalami kanaikan Rp.14.444.204.283 persentase SA tahun 2017\&2018 mengalami kenaikan Rp.892.340.305.062 persentase LB tahun 2017\&2018 mengalami kenaikan Rp.195.586.541.936 persentase PU tahun 2017\&2018 mengalami kenaikan Rp.201.805.615.183 persentase LK tahun 2017\&2018 mengalami kenaikan Rp.167.291.106.923 persentase PROF tahun 2017\&2018 mengalami kenaikan Rp.725.049.198.139 persentase AR tahun 2017\&2018 mengalami penurunan RP.103.705.829.310.

\section{STUDI LITERATUR \\ Teori Pengaruh Struktur Modal Terhadap Arus Kas}

Menurut Riyanto (KP, 2008), "Struktur modal merupakan perbandingan hutang jangka panjang dengan modal sendiri. Struktur modal terdiri dari dua komponen yaitu utang jangka panjang dan modal sendiri." Menurut Yusrianti (Wardani \& Christiyanti, 2018), "Ketika perusahaan menggunakan utang biaya modal akan dibebankan sebesar biaya bunga yang dibebankan kepada kreditur." Hutang yang tinggi memicu tingginya biaya modal, serta dapat menurunkan profitabilitas perusahaan (Utami,2009:39). Saat profitabilitas turun, arus kas perusahaan dapat mengarah negatif, sehingga perusahaan akan menggunakan cash holding untuk menutup biaya modal. Akibat dari penggunaan cash holding dapat menyebabkan sensitivitas arus kas.

\section{$\mathrm{H}_{1}$ : Struktur modal berpengaruh secara parsial terhadap arus kas pada perusahaan jasa yang terdaftar di Bursa Efek Indonesia.}

\section{Teori Pengaruh Struktur Aset Terhadap Arus Kas}

Menurut Dwi dkk.(Deviden et al., 2010), "Struktur aset adalah penentu besarnya alokasi masing-masing komponen aset tetap dan aset lancar." Menurut Jhoni dan Lina (Wardani \& Christiyanti, 2018) "Struktur aset menggambarkan perbandingan antara total aset tetap dengan total aset perusahaan." Perbandingan antara jumlah aset tetap dengan jumlah aset adalah untuk mengalokasikan kas yang dikeluarkan untuk pendanaan operasional perusahaan agar terhindar dari resiko kebangkrutan. Teori kontrak hutang (debt covenant hypothesis) berisi perjanjian yang mengharuskan peminjam memenuhi syarat yang disepakati (Scott, 2000). Sifat aset tetap yang tidak liquid dapat membuat perusahaan sulit untuk memenuhi kewajibannya dalam waktu dekat. Dengan demikian, diharapkan perusahaan dapat meningkatkan pencadangan kas untuk melunasi kewajiban yang dapat bersifat rutinitas. Pencadangan kas yang dilakukan secara rutin tersebut diharapkan dapat meminimalisir arus kas dapat mengarah negatif. Sehingga, saat perusahaan dapat mengalokasikan kas atau dana dengan baik (penstrukturan aset) maka tingkat sensitivitasnya akan semakin kecil.

$\mathrm{H}_{2}$ : Struktur aset tidak berpengaruh secara parsial terhadap arus kas pada perusahaan jasa yang terdaftar di Bursa Efek Indonesia.

\section{Teori Pengaruh Laba Bersih Terhadap Arus Kas}

Menurut Kieso (Rispayanto, 2013), "Laba bersih merupakan selisih antara seluruh pendapatan dari kegiatan operasi maupun non operasi perusahan. laba bersih dapat berpengaruh dalam memprediksi arus kas operasi di masa mendatang karena laba bersih bersifat akrual yang berasal dari laba sebelum pajak ditambah pendapatan lain-lain seperti pendapatan bunga dan dikurangkan dengan beban lain-lain seperti beban bunga dan beban pajak. Laba bersih merupakan selisih antara seluruh pendapatan dari kegiatan operasi maupun non operasi perusahan. Laba bersih dapat berpengaruh dalam memprediksi arus kas operasi di masa mendatang karena laba bersih bersifat akrual yang berasal dari laba sebelum pajak ditambah pendapatan lain-lain seperti pendapatan bunga dan dikurangkan dengan beban lain-lain seperti beban bunga dan beban pajak. 
$\mathrm{H}_{3}$ : Laba bersih berpengaruh secara parsial terhadap arus kas pada perusahaan jasa yang terdaftar di Bursa Efek Indonesia.

\section{Teori Pengaruh Piutang Usaha Terhadap Arus Kas}

Menurut Samryn (Ilmiah et al., 2016), "Piutang usaha merupakan tagihan kepada pihak ketiga yang terjadi karena penjuali produk atau jasa utamanya secara kreditur." Piutang usaha timbul pada saat perusahaan melakukan penjulan barang atau jasa secara kredit dan berhak atas penerimaan kas di masa mendatang. Menurut Bambang Riyanto (2008:90), piutang sebagai elemen dari modal kerja selalu dalam keadaan berputar. Periode perputaran atau periode terikatnya modal dalam piutang dipengaruhi oleh syarat pembayarannya. Semakin lunak syarat pembayarannya berarti semakin lama modal tersebut terikat dalam Piutang ini berarti tingkat perputarannya semakin rendah. Tingkat perputaran yang tinggi menunjukan cepatnya Piutang dilunasi oleh debitur. Semakin tinggi tingkat perputaran maka semakin cepat pula Piutang menjadi kas.

$\mathrm{H}_{4}$ : Piutang usaha berpengaruh secara parsial terhadap arus kas pada perusahaan jasa yang terdaftar di Bursa Efek Indonesia.

\section{Teori Pengaruh Likuiditas Terhadap Arus Kas}

Menurut Kasmir (Yusra, 2016), "Likuiditas merupakan rasio yang menggambarkan kemampuan perusahaan memenuhi kewajiban (utang) jangka pendek." Likuiditas mempunyai tujuan untuk melakukan uji kecukupan dana, solvency perusahaan, kemampuani perusahaan membayar kewajiban-kewajiban yang segera harus dipenuhi. Menurut Tommy (Cahyanti et al., 2017) " likuiditas berpengaruh signifikan terhadap arus kas bebas perusahaan." Nilai current ratio yang baik bagi perusahaan akan dapat meningkatkan kepercayaan investor. Tentang konsetrasi kepemilikan saham, risiko perusahaan, likuiditas saham, arus kas, dan nilai perusahaan dimana hasil penelitian menunjukkan bahwa dalam likuiditas saham berpengaruh signifikan terhadap arus kas.

\section{$\mathrm{H}_{5}$ : Likuiditas tidak berpengaruh secara parsial terhadap arus kas pada perusahaan jasa yang terdaftar di Bursa Efek Indonesia.}

\section{Teori Pengaruh Profitabilitas Terhadap Arus Kas}

Menurut Kamir (Cahyanti et al., 2017), "Profitabilitas adalah rasio untuk menilai kemampuan perusahaan dalam mencari keuntungan." Rasio ini juga memberikan ukuran tingkat efektivitas manajemen suatu perusahaan. Daya tarik bagis pemilih perusahaan yaitu pemegang saham dalam suatuk perseroan adalah profitabilitas. Profitabilitas Harahap (Jariyah \& Budiarti, 2019), "Profitabilitas menunjukkan kemampuan perusahaan memperoleh laba diukur dari jumlah laba sebelum dikurangi bunga dan pajak dibandingkan dengan total aktiva. Semakin besar rasio profitabilitas, maka perusahaan jauh dari kondisi financial distres. Setiap perusahaan ingin mendapatkan laba yang stabil dan terus meningkat dengan begitu menumbuhkan rasa percaya diri bagi investor untuk menanamkan modal pada perusahaan. jika laba tinggi maka kinerja perusahaan dapat dikatakan baik yang artinya manajer mampu untuk menjalankan usahanya. Apabila perusahaan mempunyai profitabilitas rendah maka perusahaan dalam kondisi buruk.

H$_{6}$ : Profitabilitas berpengaruh secara parsial terhadap arus kas pada perusahaan jasa yang terdaftar di Bursa Efek Indonesia.

\section{METODE}

Penelitian ini menggunakan teknik analisis data dalam penelitian kuantitatif menggunakan teknik statistik dengan bantuan program IBM SPSS. Metode analisis data dalam penelitian ini menggunakan regresi linier berganda. Menurut Ghozali (Salsabila \& Iriyadi, 2020), "Analisis regresi pada dasarnya adalah studi mengenai ketergantungan variabel dependen/terikat dengan satu atau lebih variabel independen variabel bebas/penjelas dengan tujuan untuk mngestimasi dan memprediksi rata-rata." Populasi atau nilai rata-rata variabel independen berdasarkan nilai variabel independen. 


\section{Pendekatan Penelitian}

Pendekatan penelitian yang digunakan dalam penelitian ini adalah penelitian kuantitatif. Menurut Sugiyono (Triana, 2019), "Penelitian kuantitatif adalah metode penelitian yang berlandaskan pada filsafat positif digunakan untuk meneliti pada populasi ataupun sampel tertentu, pengumpulan data menggunakan instrumen penelitian, analisis data bersifat kuantitatif atau statistik, dengan tujuan untuk menguji hipotesis yang telah ditetapkan." Penelitian ini menggunakan metode penelitian kuantitatif, dengan tujuan untuk menguji hipotesis yang telah ditetapkan dan untuk mengetahui pengaruh dari variabel bebas (independent) pada variabel terikat (dependent). Penelitian ini menganalisis dan menguji apakah variabel kualitas layanan berpengaruh pada kepuasan pelanggan.

\section{Jenis Penelitian}

Penelitian ini merupakan penelitian kuantitatif asosiatif yaitu penelitian yang dilakukan untuk mencari tahu ada tidaknya pengaruh dari struktur modal, struktur aset, laba bersih, piutang usaha, likuiditas, profitabilitas terhadap arus kas.

\section{Populasi dan Sampel}

Menurut Nursalam (Koentarto \& Hasaruddin, 2021)"Populasi adalah keseluruhan dari variabel yang menyangkut masalah yang diteliti." Menurut Nana Sudjana dan Ibrahim (Affandi \& Sofiati, 2019), "Sampel adalah sebagian dari populasi yang diambil sampelnya." Teknik pengambilan sampel yang digunakan adalah dalam penelitian ini berdasarkan Purposive Sampling. Penelitian ini bertujuan untuk mengetahui determi an arus kas yang terdaftar di Bursa Efek Indonesia. Oleh karena itu, populasi yang digunakan dalam penelitian ini adalah seluruh perusahaan yang terdaftar di BEI. Namun, karena beberapa keterbatasan, penelitian ini hanya mengunakan sebagian perusahaan yang terdaftar.

Populasi penelitian ini adalah 78 Perusahaan Jasa yang tercatat di Bursa Efek Indonesia periode 2017-2019. Sampel yang digunakan adalah metode purposive sampling method. Metode ini digunakan karena sebuah penelitian yang memerlukan kriteria khusus agar sampel yang diambil nantinya sesuai dengan tujuan penelitian dapat memecahkan permasalahan penelitian serta dapat memberikan nilai yang lebih representatif. Beberapa kriteria dalam pengunaan sampel:

Tabel 2. Kriteria Pemilihan Sampel

\begin{tabular}{|c|l|l|}
\hline No. & \multicolumn{1}{|c|}{ Keterangan } & \multicolumn{1}{|c|}{ Jumlah } \\
\hline 1 & $\begin{array}{l}\text { Perusahaan yang laporan keuangannya terdaftar di Bursa Efek } \\
\text { Indonesia }\end{array}$ & 78 \\
\hline 2 & $\begin{array}{l}\text { Perusahaan yang tidak mempublikasikan laporan keuangan } \\
\text { secara rutin di Bursa Efek Indonesia }\end{array}$ & $(40)$ \\
\hline 3 & Perusahaan yang mengalami kerugian di Bursa Efek Indonesia & $(26)$ \\
\hline Jumlah sampel penelitian & $\mathbf{1 2}$ \\
\hline \multicolumn{2}{|c|}{ Total Sampel (12 perusahaan x 3 tahun) }
\end{tabular}

Sumber: Hasil Pengolahan Data ( 2021)

\section{Uji Asumsi Klasik}

Uji normalitas dilakukan untuk sebuah tujuan menilai adanya sebaran data padat sekelompok data ataupun variabel untuk mengetahui apakah sebaran data itu dapat berdistribusi dengang norma atau tidak. Uji multikolinieritas pada penelitian ini mempunyai tujuan untuk pengujian adanya korelasi antara variabel bebas dan variabel independen, multikolinieritas dapat terjadi jika nilai tolerancenya di bawah 0,1 dan VIF di atas 10. Menurut Ghozali (Rakhman, 2020), "Uji multikolinieritas bertujuan untuk menguji apakah suatu model regresi terdapat korelasi antar variabel bebas/independen tolerance mengukur variabel indepeneden yang terpilih yang tidak dijelaskan oleh variabel independen lainnya." Uji autokorelasi menggunakan metode uji runs (run test). Menurut Ghozali ( 
regresi ada korelasi antara kesalahan pengganggu pada periode-t dengan kesalahan pengganggu pada periode t-t1 (sebelumnya)." Uji heterokedastisitas pada penelitian ini bertjujuan untuk pengujian apakah di dalam model regresi dapat terjadi ketidaksamaan varian ataupun residual. Menurut Gujarati (Bawawa et al., 2021), "Untuk menguji ada tidaknya heterokedastisitas digunakan uji Rank-Spearman yaitu dengan mengkorelasikan variabel independen terhadap nilai absolute dari residual (error)."

\section{Model Analisis Peneltian}

Dalam penelitian ini, metode yangi digunakan yaitus metode analisis statistik. Sebelum data akan dianalisis, terlebih dahulu dilakukan uji t asumsi klasik sebelum melakukan pengujian hipotesis. Analisis dalam mengolah data menggunakan SPSS (Statistical Productand Service Solution). Model analisis data menggunakan analisis regresi berganda untuk mengetahui pengaruh variable bebas (independen) dan variable terikat/dependen digunakan rumus analisis regresi linier berganda sebagai berikut:

$$
Y=a+b_{1} X_{1}+b_{2} X_{2}+b_{3} X_{3}+b_{4} X_{4}+b_{5} X_{5}+b_{6} X_{6}+e
$$

\section{Uji Signifikan Secara Simultan (Uji-F)}

Menurut Sunyoto(Purba et al., 2020), "Uji F dilakukan untuk mengetahui pengaruh antara variabel bebas terhadap variabel terikat secara bersama-sama/simultan." Untuk menguji hipotesia ini digunakan statitik $\mathrm{F}$ dengan membandingkan nilai $\mathrm{F}$ hasil perhitungan dengan nilai $\mathrm{F}$ menurut tabel, yaitu:

a. $\mathrm{H}_{\mathrm{o}}$ diteriman ataus $\mathrm{H}_{\mathrm{a}}$ ditolak jika $\mathrm{F}_{\text {hitung }} \leq . \mathrm{F}_{\text {tabel }}$ dan nilai $\operatorname{sig}>0,05$

b. $\mathrm{H}_{\mathrm{a}}$ diterima atau $\mathrm{H}_{\mathrm{o}}$ ditolak jika $\mathrm{F}_{\text {hitung }}>\mathrm{F}_{\text {tabel }}$ dan nilai sig $<0,05$

\section{Uji Signifikan Secara Parsial (Uji-t)}

Menurut Sunyoto (Purba et al., 2020) "Uji t digunakan untuk mengetahui ada atau tidaknya hubungan atau pengaruh yang berarti atau signifikan antara variabel bebas secara parsial terhadap variabel terikat." Kriteria pengujian hipotesis penelitian adalah sebagai berikut:

a. $\mathrm{H}_{\mathrm{o}}$ diterima atau $\mathrm{H}_{\mathrm{a}}$ ditolak jika $t_{\text {hitung }} \leq \mathrm{t}_{\text {tabel }}$ dan nilai sig. $>0,05$.

b. $\mathrm{H}_{\mathrm{a}}$ diterima atau $\mathrm{H}_{\mathrm{o}}$ ditolak jika $\mathrm{t}_{\text {hitung }}<\mathrm{t}_{\text {tabel }}<\mathrm{t}_{\text {hitung }}$ dan nilai sig. $<0,05$.

HASIL

Tabel 3. Hasil Statistik Deskriptif

\begin{tabular}{|l|l|l|l|l|l|}
\hline & $\mathrm{N}$ & Minimum & Maksimum & Rata-rata & Standar Deviasi \\
\hline Struktur modal & 36 & .00 & 1.33 & .2837 & .3270 \\
\hline Struktur aset & 36 & .00 & .82 & .2400 & .1816 \\
\hline Laba bersih & 36 & 1.00 & 976.00 & 210.6389 & 284.7893 \\
\hline Piutang usaha & 36 & 1.00 & 847.00 & 211.1667 & 254.4262 \\
\hline Likuiditas & 36 & .00 & 3.98 & 1.1092 & 1.0361 \\
\hline ROE & 36 & .01 & .56 & .1243 & .0987 \\
\hline Arus kas & 36 & 1.00 & 997.00 & 190.8333 & 285.2896 \\
\hline Valid N (listwise ) & 36 & & & & \\
\hline
\end{tabular}

Sumber Tabel : Hasil Pengolahan Data (2021)

\section{Uji Normalitas}

Pengujian normalitas dilakukan dalam uji regresi dengan tujuan untuk melihat apakah residual terdistribusi dengan normal atau tidak dalam pengujian normalitas ini menggunakan 3 metode yaitu dengan menganalisis uji normal probability plot, grafik histogram, dan uji one sample $K S$. 


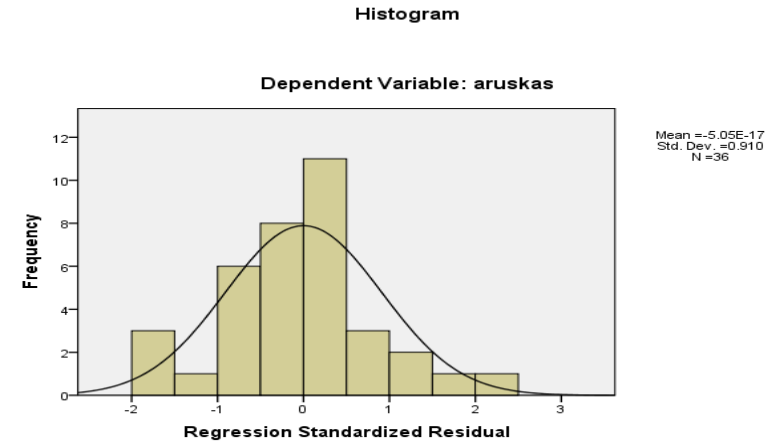

Gambar 1. Normalitas Grafik Histogram

Sumber: Hasil Pengolahan Data (2021)

Pada gambar diatas dapat kita lihat bahwa garis kurva yang condong simestri (U) terbalik. Gambar tersebut menunjukkan bahwa data terdistribusi dengan normal, karna pola distribusi grafik histogram tidak condong kekiri maupun kekanan.

\section{Uji Multikolinieritas}

Uji multIkolinieritas berguna dalam menguji model regresi yang bertujuan untuk menemukan hubungan diantara variabel bebas.

\begin{tabular}{|l|r|r|}
\hline \multirow{2}{*}{\multicolumn{2}{|c|}{ Model }} & \multicolumn{2}{c|}{ Collinearity Statistics } \\
\cline { 2 - 3 } \multicolumn{2}{|c|}{ Tolerance } & \multicolumn{2}{c|}{ VIF } \\
\hline $1 \quad$ constant) & .337 & 2.970 \\
\hline Struktur Modal & .939 & 1.065 \\
\hline Struktur Aset & .562 & 1.778 \\
\hline Laba Bersih & .595 & 1.860 \\
\hline Piutang Usaha & .338 & 2.961 \\
\hline Likuiditas & .935 & 1.069 \\
\hline ROE &
\end{tabular}

Tabel 4. Hasil Uji Multikolinieritas

Sumber: Hasil Pengolahan Data (2021)

Pada tabel di atas, dapat dilihat dibagian nilai VIF menunjukkan nilai $<10$ dan dibagian nilai tolerance menunjukkan nilai $>0.10$. Jadi dapat disimpulkan bahwa data tersebut bebas dari gejala multikolinieritas.

\section{Uji Autokorelasi}

Adanya uji auto korelasi dilakukan untuk melihat dan menguji hubungan antara kesalahan pengganggu pada suatu periode dengan periode sebelumnya. Pada penelitian ini peneliti menggunakan metode Run Test.

Tabel 5. Hasil Uji Autokorelasi

\begin{tabular}{|l|r|}
\hline Runs Test & Unstandardized Residual \\
\hline Test Value ${ }^{\mathrm{a}}$ & 2,08968 \\
\hline Cases $<$ Test Value & 18 \\
\hline Cases >= Test Value & 18 \\
\hline Total Cases & 36 \\
\hline Number of Runs & 16 \\
\hline
\end{tabular}


Owner: Riset \& Jurnal Akuntansi

e-ISSN : 2548-9224 |p-ISSN : 2548-7507

Volume 5 Nomor 5, Agustus 2021

DOI : https://doi.org/10.33395/owner.v5i2.419

\begin{tabular}{|l|r|}
\hline Z &,- 845 \\
\hline Asymp . Sig . ( 2-tailed ) &, 398 \\
\hline
\end{tabular}

Sumber: Hasil Pengolahan Data (2021)

Pada tabel di atas dapat dilihat nilai signifikannya adalah 0.398 dalam arti menunjukkan bahwa dalam data tersebut tidak ada gejala auto korelasi karna nilai signifikannya melebihi 0.05

\section{Uji Heterokedastisitas}

Dalam uji heterokedastisitas ada beberapa teknik yang dapat digunakan untuk menguji adanya heterokedastisitas yang terdapat pada varian error terms pada model regresi.

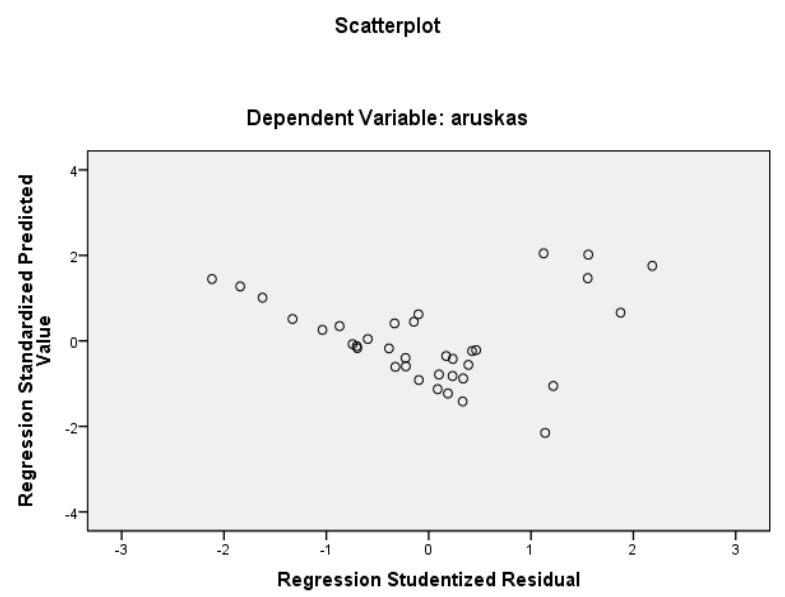

Gambar 2. Grafik Scatterplot

Sumber: Hasil Pengolahan Data (2021)

Pada gambar scatterplot terlihat titik berpencar tidak beraturan dan menyebar keatas dan kebawah atau tidak berkumpul pada satu titik, jadi gambar ini menunjukkan tidak terdapat heterokedastisitas.

\section{Model Penelitian}

Tabel 6. Regresi Linier Berganda

\begin{tabular}{|c|c|c|c|c|c|c|c|c|}
\hline & \multicolumn{2}{|c|}{$\begin{array}{r}\text { Unstanddardized } \\
\text { Coefficients }\end{array}$} & \multirow{2}{*}{$\begin{array}{l}\text { Standardized } \\
\text { Coefficients } \\
\text { Beta }\end{array}$} & \multirow[b]{2}{*}{$\mathrm{t}$} & \multirow[b]{2}{*}{ Sig. } & \multicolumn{2}{|l|}{$\begin{array}{l}\text { Collinearity } \\
\text { Statistics }\end{array}$} \\
\hline & & $\mathrm{B}$ & Std. Error & & & & Tolerance & VIF \\
\hline \multirow[t]{7}{*}{1} & (constant) & 107.133 & 114.536 & & .935 & .357 & & \\
\hline & $\begin{array}{l}\text { Struktur } \\
\text { modal }\end{array}$ & -288.698 & 214.503 & -.331 & $\begin{array}{r}- \\
1.346\end{array}$ & .189 & .337 & 2.970 \\
\hline & Struktur aset & -77.545 & 231.227 & -.049 & -.335 & .740 & .939 & 1.065 \\
\hline & Laba bersih & .748 & .191 & -.747 & 3.927 & .000 & .562 & 1.778 \\
\hline & $\begin{array}{l}\text { Piutang } \\
\text { usaha }\end{array}$ & -.425 & .207 & -.379 & 2.052 & .049 & .595 & 1.860 \\
\hline & Likuiditas & 76.024 & 67.585 & .276 & 1.125 & .270 & .338 & 2.961 \\
\hline & ROE & 258.313 & 426.248 & .089 & .606 & .549 & .935 & 1.069 \\
\hline
\end{tabular}

Sumber: Hasil Pengolahan Data (2021)

Pada tabel di atas dapat dibuat persamaan regresi sebagai berikut:

$$
\begin{aligned}
\widehat{Y}=107.133- & 288.698 X_{1}-77.545 X_{2}+0.748 X_{3}-0.425 X_{4}+76.024 X_{5} \\
& +2^{258.313 X_{6}}
\end{aligned}
$$


Owner: Riset \& Jurnal Akuntansi

e-ISSN : 2548-9224 |p-ISSN : 2548-7507

Volume 5 Nomor 5, Agustus 2021

DOI : https://doi.org/10.33395/owner.v5i2.419

\section{Koefisien Determinasi $\left(\mathbf{R}^{2}\right)$}

Tabel 7. Hasil Koefisien Determinasi

\begin{tabular}{|l|l|r|r|rr|}
\hline Model & $\mathrm{R}$ & R Square & Adjusted R Square & Std.Error of the Estimate \\
\hline 1 & $.640^{\mathrm{a}}$ & .410 & .288 & & 240.76912 \\
\hline
\end{tabular}

Sumber: Hasil Pengolahan Data (2021)

Pada tabel di atas dapat dilihat nilai Adjusted R Square adalah 0.288 berarti dapat disimpulkan bahwa pada variabe struktur modal, struktur aset, laba bersih, piutang usaha, likuiditas, ROE dapat dijelaskan hubungannya dengan variabel arus kas dengan nilai sebesar $28.8 \%$ dan sisanya $71.2 \%$ dapat diterangkan oleh variabel independen lain yang tidak diteliti dalam penelitian ini.

\section{Pengujian Hipotesis Secara Simultan (Uji F)}

Dalam pengujian koefisien secara simultan dapat dilakukan dengan menggunakan Uji $F$ Uji F dapat dipakai untuk memperlihatkan semua variabel independent yang dapat mempengaruhi secara bersamaan variabel dependennya

Tabel 8. Hasil Uji F

\begin{tabular}{|l|l|c|r|r|r|c|}
\hline \multicolumn{7}{|c|}{ ANOVA $^{\mathbf{b}}$} \\
\multicolumn{2}{|l|}{ Model } & $\begin{array}{c}\text { Sum of } \\
\text { Squares }\end{array}$ & \multicolumn{1}{c|}{ df } & $\begin{array}{c}\text { Mean } \\
\text { Square }\end{array}$ & F & Sig. \\
\hline \multirow{3}{*}{1} & Regression & 1167531.733 & 6 & 194588.622 & 3.357 & $.012^{\mathrm{a}}$ \\
\cline { 2 - 7 } & Residual & 1681123.267 & 29 & 57969.768 & & \\
\cline { 2 - 8 } & Total & 2848655.000 & 35 & & & \\
\hline
\end{tabular}

a. Predictors: (Constant), ROE, strukturaset, likuiditas, piutangusaha, lababersih, struktur modal

b. Dependent Variable : aruskas

Sumber: Hasil Pengolahan Data ( 2021)

Dari tabel di atas dapat dilihat nilai $\mathrm{F}_{\text {hitung }}$ sebesar 3.357 dan didapat nilai $\mathrm{F}_{\text {tabelnya }}$ sebesar 2.43 dimana dikatakan jika nilai $\mathrm{F}_{\text {hitung }}>\mathrm{F}_{\text {tabel }}=3.357>2.43$ maka artinya $\mathrm{H}_{\mathrm{o}}$ ditolak dan $\mathrm{H}_{\mathrm{a}}$ diterima, jadi dapat ditarik kesimpulan bahwa jika nilai $\mathrm{F}_{\text {hitung }}>\mathrm{F}_{\text {tabel }}$ dan nilai sig lebih $<0.05$ maka variabel struktur modal, struktur aset, laba bersih, piutang usaha, likuiditas, ROE secara simultan berpengaruh terhadap arus kas.

\section{Pengujian Hipotesis Secara Parsial (Uji t)}

Tabel 9. Hasil Uji t

\begin{tabular}{|c|c|c|c|c|c|c|c|c|}
\hline & \multirow[t]{2}{*}{4} & \multicolumn{2}{|c|}{$\begin{array}{r}\text { Unstanddardized } \\
\text { Coefficients } \\
\end{array}$} & \multirow{2}{*}{$\begin{array}{l}\text { Standardized } \\
\text { Coefficients } \\
\text { Beta }\end{array}$} & \multirow[b]{2}{*}{$\mathrm{t}$} & \multirow[b]{2}{*}{ Sig. } & \multicolumn{2}{|l|}{$\begin{array}{l}\text { Collinearity } \\
\text { Statistics }\end{array}$} \\
\hline & & B & Std. Error & & & & Tolerance & VIF \\
\hline \multirow[t]{7}{*}{1} & (constant) & 107.133 & 114.536 & & .935 & .357 & & \\
\hline & $\begin{array}{l}\text { Struktur } \\
\text { modal }\end{array}$ & -288.698 & 214.503 & -.331 & -1.346 & .189 & .337 & 2.970 \\
\hline & Struktur aset & -77.545 & 231.227 & -.049 & -.335 & .740 & .939 & 1.065 \\
\hline & Laba bersih & .748 & .191 & -.747 & 3.927 & .000 & .562 & 1.778 \\
\hline & $\begin{array}{l}\text { Piutang } \\
\text { usaha }\end{array}$ & -.425 & .207 & -.379 & -2.052 & .049 & .595 & 1.860 \\
\hline & Likuiditas & 76.024 & 67.585 & .276 & 1.125 & .270 & .338 & 2.961 \\
\hline & ROE & 258.313 & 426.248 & .089 & .606 & .549 & .935 & 1.069 \\
\hline
\end{tabular}

Sumber: Hasil Pengolahan Data (2021)

1. Struktur Modal $\mathrm{t}_{\text {hitung }}=-1.345$, sig $=189$, $\mathrm{t}_{\text {hitung }}<\mathrm{t}_{\text {tabel }}$ yaitu $-1.345<2.045$ maka $\mathrm{H}_{\mathrm{o}}$ tidak ditolak dan $\mathrm{H}_{\mathrm{a}}$ ditolak berarti Struktur Modal tidak berpengaruh terhadap arus kas pada perusahaan Jasa yang terdaftar di Bursa Efek Indonesia Periode 2017-2019 
2. Struktur Aset $\mathrm{t}_{\text {hitung }}=-0.335$, sig 0.740 , $\mathrm{t}_{\text {hitung }}<\mathrm{t}_{\text {tabel }}$ yaitu $-0.335<2.045$ maka $\mathrm{H}_{\mathrm{o}}$ tidak ditolak dan $\mathrm{H}_{\mathrm{a}}$ ditolak berarti Struktur Aset tidak berpengaruh terhadap arus kas pada perusahaan Jasa yang terdaftar di Bursa Efek Indonesia Periode 2017-2019

3. Laba bersih $\mathrm{t}_{\text {hitung }}=3.927$, sig 0.000 , $\mathrm{t}_{\text {hitung }}>3.927>2.045$ maka $\mathrm{H}_{\mathrm{o}}$ ditolak dan $\mathrm{H}_{\mathrm{a}}$ diterima berarti Laba Bersih berpengaruh terhadap arus kas pada perusahaan Jasa yang terdaftar di Bursa Efek Indonesia Periode 2017-2019

4. Piutang Usaha $\mathrm{t}_{\text {hitung }}=2.052$, sig $=0.049$, $\mathrm{t}_{\text {hitung }}>\mathrm{t}_{\text {tabel }}$ yaitu $2.052>2.045 \mathrm{maka}_{\mathrm{o}}$ ditolak dan $\mathrm{H}_{\mathrm{a}}$ diterima berarti Piutang Usaha berpengaruh terhadap arus kas pada perusahaan Jasa yang terdaftar di Bursa Efek Indonesia Periode 2017-2019

5. Likuiditas $t_{\text {hitung }}=1.125$, sig=0.270, $t_{\text {hitung }}<t_{\text {tabel }}$ yaitu $1.125<2.045$ maka $H_{o}$ diterima dan $H_{a}$ ditolak berarti Likuiditas tidak berpengaruh terhadap arus kas pada perusahaan Jasa yang terdaftar di Bursa Efek Indonesia Periode 2017-2019

6. Return On Equity ( ROE) $t_{\text {hitung }}=0.606$, sig $=0.549$, $t_{\text {hitung }}<t_{\text {tabel }}$ yaitu $0.606<2.045$ maka $\mathrm{H}_{\mathrm{o}}$ diterima dan $\mathrm{H}_{\mathrm{a}}$ ditolak berarti Return On Equity ( $\mathrm{ROE}$ ) tidak berpengaruh terhadap arus kas pada perusahaan Jasa yang terdaftar di Bursa Efek Indonesia Periode 2017-2019

\section{Pengaruh Struktur Modal Terhadap Arus Kas}

\section{PEMBAHASAN}

Hasil penelitian ini adalah Struktur Modal tidak berpengaruh terhadap arus kas pada perusahaan Jasa yang terdaftar di Bursa Efek Indonesia periode 2017-2019.

Hasil penelitian ini tidak sejalan dengan penelitian (Kusuma Wardani \& Vivi Christiyanti, 2018) yang menyatakan adanya pengaruh struktur modal terhadap cash flow shock dalam koefisien positif.

\section{Pengaruh Struktur Aset Terhadap Arus Kas}

Hasil penelitian ini adalah Struktur Aset tidak berpengaruh terhadap arus kas pada perusahaan Jasa yang terdaftar di Bursa Efek Indonesia periode 2017-2019.

Hasil penelitian ini sejalan dengan Wetson and Copeland (Kusuma Wardani \& Vivi Christiyanti, 2018), menerangkan tidak adanya pengaruh struktur aset terhadap cash flow shock.

\section{Pengaruh Laba Bersih Terhadap Arus Kas}

Hasil penelitian ini adalah Laba Bersih berpengaruh terhadap arus kas pada perusahaan Jasa yang terdaftar di Bursa Efek Indonesia periode 2017-2019.

Hasil penelitian ini tidak sejalan dengan (Rispayanto, 2013), yang menyatakan bahwa variabel laba bersih tidak berpengaruh dalam memprediksi arus kas operasi masa mendatang.

\section{Pengaruh Piutang Usaha Terhadap Arus Kas}

Hasil penelitian ini adalah Piutang Usaha berpengaruh terhadap arus kas pada perusahaan Jasa yang terdaftar di Bursa Efek Indonesia periode 2017-2019.

Hasil penelitian ini sejalan dengan Bambang Riyanto (2008), semakin tinggi tingkat perputaran maka semakin cepat pula piutang menjadi kas. Selain itu cepatnya Piutang dilunasi menjadi kas berarti kas akan digunakan kembali sehingga resiko kerugian.

\section{Pengaruh Likiditas Terhadap Arus Kas}

Hasil penelitian ini adalah Likuiditas tidak berpengaruh terhadap arus kas pada perusahaan Jasa yang terdaftar di Bursa Efek Indonesia periode 2017-2019.

Hasil penelitian ini tidak sejalan dengan Tommy (Cahyanti et al., 2017) yang menyatakan bahwa likuiditas berpengaruh signifikan terhadap arus kas bebas perusahaan. Nilai current ratio yang baik bagi perusahaan akan dapat meningkatkan kepercayaan investor.

\section{Pengaruh Return On Equity (ROE) Terhadap Arus Kas}

Hasil penelitian ini adalah Likuiditas tidak berpengaruh terhadap arus kas pada perusahaan Jasa yang terdaftar di Bursa Efek Indonesia periode 2017-2019. 
Hasil penelitian ini tidak sejalan dengan Profitabilitas Harahap (Veky et al., 2015) menyatakan bahwa rasio profitabilitas menunjukkan kemampuan perusahaan memperoleh laba diukur dari jumlah laba sebelum dikurangi bunga dan pajak dibandingkan dengan total aktiva. Semakin besar rasio profitabilitas, maka perusahaan jauh dari kondisi financial distress.

\section{KESIMPULAN}

Setelah peneliti melakukan pengolahan data dengan SPSS, maka peneliti dalam penelitian ini menyimpulkan bahwa pada uji t (parsial) variabel Struktur modal,Struktur aset, likuiditas, ROE tidak memberikan pengaruh terhadap variabel arus kas pada perusahaan Manufaktur yang terdaftar di Bursa Efek Indonesia periode 2017-2019 sedangkan variabel Piutang Usaha, Laba bersih memiliki pengaruh yang signifikan terhadap variabel arus kas pada perusahaan Jasa yang terdaftar di Bursa Efek Indonesia periode 2017-2019, dan secara uji f (simultan) variabel Struktur modal,Struktur aset, laba bersih, piutang usaha, likuiditas, ROE tidak memberikan pengaruh terhadap variabel arus kas pada perusahaan jasa yang terdaftar di Bursa Efek Indonesia periode 2017-2019. Disarankan kepada sub-sektor perdagangan besar dan eceran yang terdaftar di Bursa Efek Indonesia agar selalu mempertahankan laba agar setiap tahun makin meningkat dan tidak terjadi minus laba pada perusahaan. Karna dengan makin meningkat laba pada setiap perusahaan maka nilai sebuah perusahaan itu akan semakin bagus dan kuat sehingga para investor tidak akan ragu untuk ikut dalam menambah jumlah investasi yang mereka berikan. Adapun kelemahan dalam penelitian ini yaitu: Objek penelitian ini hanya di fokuskan pada perusahaan jasa yang mana hanya satu perusahaan yang digunakan dari banyaknya Perusahaan yang terdapat di Bursa Efek Indonesia. Dalam segi pembuatan skripsi ada beberapa keterbatasan penelitian yang terkait dengan sistematika penulisan skripsi. Disarankan kepada sub sektor perdagangan besar dan eceran yang terdaftar di Bursa efek Indonesia agar selalu mempertahankan laba agar setiap tahun makin meningkat dan tidak terjadi minus laba pada perusahaan. Karna dengan makin meningkat laba pada setiap perusahaan maka nilai sebuah perusahaan itu akan semakin bagus dan kuat sehingga para investor tidak akan ragu untuk ikut dalam menambah jumlah investasi yang mereka berikan.

\section{REFERENSI}

Affandi, D., \& Sofiati, N. (2019). Dampak Sistem Bonus Dan Tarif PT. Gojek Terhadap Kualitas Pelayanan Transportasi Berbasis Online "Gojek." In Jurnal Enersia Publika (Vol. 3, Issue 1). https://www.ejournal.up45.ac.id/index.php/Jurnal_Enersia_Publika/article/view/618 Bawawa, A., Lengkong, V., Taroreh, R., Audi Bawawa, A., Lengkong, V. P., Taroreh, R. N., Ekonomi dan Bisnis, F., \& Manajemen Universitas Sam Ratulangi, J. (2021). PENGARUH KEPUASAN KERJA, KOMITMEN ORGANISASIONAL DAN STRES KERJA TERHADAP TURNOVER INTENTION PADA PT. SIG ASIA KOTA BITUNG EFFECT OF JOB SATTISFACTION, ORGANIZATIONAL COMMITMENT AND JOB STRESS ON TURNOVER INTENTION AT PT.SIG ASIA BITUNG CITY. Jurnal EMBA: Jurnal Riset Ekonomi, Manajemen, Bisnis Dan Akuntansi, 9(2), 785-795. https://ejournal.unsrat.ac.id/index.php/emba/article/view/33750

Cahyanti, D. A., Nuraina, E., \& Wijaya, A. L. (2017). Pengaruh Likuiditas, Profitabilitas, dan Leverage Terhadap Arus Kas Masa Mendatang Pada Perusahaan Properti dan Real Estate di BEI. Assets: Jurnal Akuntansi Dan Pendidikan, 6(1), 26. https://doi.org/10.25273/jap.v6i1.1291

Deviden, K., Aset, S., Perusahaan, U., \& Pertumbuhan Penjualan, D. (2010). PENGARUH LIKUIDITAS.

Triyulianto, T., Rangkuti, T., \& Mukoronah, M. (2016). ANALISIS AKUNTANSI PIUTANG TAK TERTAGIH PADA KOPERASI USAHA MANDIRI BEKASI 2014. Jurnal Reformasi Administrasi: Jurnal Ilmiah untuk Mewujudkan Masyarakat Madani, 3(2), 159164.

Jariyah, A., \& Budiarti, A. (2019). PENGARUH RASIO LIKUIDITAS, PROFITABILITAS, DAN AKTIVITAS TERHADAP PREDIKSI FINANCIAL DISTRESS PERUSAHAAN TEKSTIL DAN GARMEN. In Jurnal Ilmu dan Riset Manajemen (JIRM) (Vol. 8, Issue 1). 
www.kemenprin.go.id

Koentarto, I. dan, \& Hasaruddin, H. (2021). Volume 6 Nomor 1 Edisi Februari 2021. Jurnal Ecoment Global : Kajian Bisnis Dan Manajemen, 6(1), 11-18. http://ejournal.uigm.ac.id/index.php/EG/article/view/1166

KP, H. N. (2008). Pengaruh Profitabilitas Fixed Asset Ratio, Kontrol Kepemilikan dan Struktur Aktiva terhadap Struktur Modal pada Perusahaan Manufaktur di Indonesia. In Sinergi: Kajian Bisnis dan Manajemen (Vol. 10, Issue 1). https://journal.uii.ac.id/Sinergi/article/view/873

Kusuma Wardani, D., \& Vivi Christiyanti, H. (2018). PENGARUH STRUKTUR ASET DAN STRUKTUR MODAL TERHADAP CASH FLOW SHOCK. https://doi.org/10.29230/ad.v2i2.2583

Nur Islamiyah, Rita Andini, A. O. (2018). ANALISIS BIAYA OPERASIONAL DAN PERPUTARAN PERSEDIAAN TERHADAP LABA BERSIH DENGAN VOLUME PENJUALAN SEBAGAI VARIABEL MODERATING (Pada Perusahaan Manufaktur Sub Sektor Kosmetik dan Keperluan Rumah Tangga yang Terdaftar di Bursa Efek Indonesia Periode 2012-20. http://jurnal.unpand.ac.id/index.php/AKS/article/view/1184

Nursyam, N. A., Amtiran, P. Y., \& Makatita, R. F. (2020). Pengaruh Struktur Modal, Struktur Kekayaan dan Struktur Keuangan Terhadap Profitabilitas. JURNAL AKUNTANSI, 9(2), 160-173. https://doi.org/10.37932/ja.v9i2.114

Purba, A. R., Hutagalung, N. Y., Putri, E., \& Nazmi, H. (2020). PENGARUH KEPEMIMPINAN, MOTIVASI DAN KEDISIPLINAN TERHADAP KINERJA KARYAWAN PADA PT. SANTIKA PREMIERE DYANDRA. In Jurnal Ilmu Manajemen METHONOMIX (Vol. 3, Issue 1). www.methonomi.net

Rakhman, M. A. (2020). HUBUNGAN KEBIJAKAN PUBLIK TERHADAP PERTUMBUHAN EKONOMI DI PROVINSI JAWA TENGAH. BISECER (Business Economic Entrepreneurship), 3(2), 17-22. http://www.ejournal.undaris.ac.id/index.php/biceser/article/view/190

Rinanda, Y., Akuntansi, A., Padang, I., Kunci, K., Arus, P., Operasi, K., Depan, M., Laba, A., \& Kas, O. (2018). PENGARUH KEMAMPUAN LABA DAN ARUS KAS OPERASI DALAM MEMPREDIKSI ARUS KAS OPERASI MASA DEPAN (STUDI EMPIRIS PADA PERUSAHAAN MANUFAKTUR YANG TERDAFTAR DI BEI). In STIE Perbankan Indonesia (Vol. 1, Issue 1). www.idx.co.id

Rispayanto, S. (2013). PENGARUH LABA KOTOR, LABA OPERASI, LABA BERSIH DAN ARUS KAS OPERASI DALAM MEMPREDIKSI ARUS KAS OPERASI MASA MENDATANG. https://sg.docs.wps.com/1/sIMOoy6A1 ofOPhAY

Salsabila, H. A., \& Iriyadi, I. (2020). Evaluasi Atas Penerapan Sistem Informasi Akademik Dan Keuangan Terhadap Tingkat Kepuasan Mahasiswa. JAS-PT (Jurnal Analisis Sistem Pendidikan Tinggi Indonesia), 4(2), 137. https://doi.org/10.36339/jaspt.v4i2.348

Triana, R. (2019). Akuntabilitas Pengelolaan Keuangan Daerah Pada Pemerintah Kota Bandung Yang Dipengaruhi Oleh Implementasi Sistem Akuntansi Keuangan Daerah Dan Implementasi Pengendalian Internal (Survey Pada Satuan Kerja Perangkat Daerah Pemerintah Kota Bandung). http://elibrary.unikom.ac.id

Veky, A., Ruliana, T., \& Masithoh, R. (2015). PROFITABILITAS PT. CHAROEN POKPHAND INDONESIA Tbk.

Wardani, D. K., \& Christiyanti, H. V. (2018). Pengaruh Struktur Aset Dan Struktur Modal Terhadap Cash Flow Shock. AKUNTANSI DEWANTARA Universitas Sarjanawiyata Tamansiswa Yogyakarta, 2(2), 124-134. https://doi.org/10.29230/ad.v2i2.2583

Yusra, I. (2016). KEMAMPUAN RASIO LIKUIDITAS DAN SOLVABILITAS DALAM MEMPREDIKSI LABA PERUSAHAAN PERUSAHAAN: STUDI EMPIRIS PADA PERUSAHAAN TELEKOMUNIKASI YANG TERDAFTAR DI BURSA EFEK INDONESIA. Jurnal Benefita, l(1), 15. https://doi.org/10.22216/jbe.v1i1.878 